\title{
Correction: Olfactory Training and Visual Stimulation Assisted by a Web Application for Patients With Persistent Olfactory Dysfunction After SARS-CoV-2 Infection: Observational Study
}

Fabrice Denis ${ }^{1}$, MD, PhD; Anne-Lise Septans ${ }^{2}$, PhD; Lea Periers ${ }^{3}$, MD; Jean-Michel Maillard ${ }^{4}$, ING; Florian Legoff ${ }^{5}$, MSc; Hirac Gurden ${ }^{6}$, PhD; Sylvain Moriniere ${ }^{3}$, MD, PhD

${ }^{1}$ Institut Inter-Regional Jean Bernard - ELSAN, Le Mans, France

${ }^{2}$ Weprom, Angers, France

${ }^{3}$ Service d'Otorhinolaryngologie, Centre Hospitalier Universitaire Bretonneau, Tours, France

4 anosmie.org Association, Alencon, France

${ }^{5}$ Kelindi, Lille, France

${ }^{6}$ Unite de Biologie Fonctionnelle Adaptative, Unite Mixte de Recherche 8251 Centre National de Recherche Scientifique, Université de Paris, Paris, France

Corresponding Author:

Fabrice Denis, MD, PhD

Institut Inter-Regional Jean Bernard - ELSAN

9 Rue Beauverger

Le Mans

France

Phone: 33684190480

Email: fabrice.denis.home@gmail.com

\section{Related Article:}

Correction of: https://www.jmir.org/2021/5/e29583

(J Med Internet Res 2021;23(7):e32120) doi: 10.2196/32120

In "Olfactory Training and Visual Stimulation Assisted by a Web Application for Patients With Persistent Olfactory Dysfunction After SARS-CoV-2 Infection: Observational Study" (J Med Internet Res 2021;23(5):e29583), one error was noted.

In the originally published article, the "Edited by" credit was listed incorrectly. This has been corrected from "Edited by $\mathrm{C}$ Basch, G Eysenbach" to "Edited by G Eysenbach".
The correction will appear in the online version of the paper on the JMIR Publications website on July 16, 2021, together with the publication of this correction notice. Because this was made after submission to PubMed, PubMed Central, and other full-text repositories, the corrected article has also been resubmitted to those repositories.

This is a non-peer-reviewed article. Submitted 15.07.21; accepted 15.07.21; published 16.07.21.

Please cite as:

Denis F, Septans AL, Periers L, Maillard JM, Legoff F, Gurden H, Moriniere S

Correction: Olfactory Training and Visual Stimulation Assisted by a Web Application for Patients With Persistent Olfactory Dysfunction After SARS-CoV-2 Infection: Observational Study

J Med Internet Res 2021;23(7):e32120

URL: https://www.jmir.org/2021/7/e32120

doi: $\underline{10.2196 / 32120}$

PMID: 34270442

CFabrice Denis, Anne-Lise Septans, Lea Periers, Jean-Michel Maillard, Florian Legoff, Hirac Gurden, Sylvain Moriniere. Originally published in the Journal of Medical Internet Research (https://www.jmir.org), 16.07.2021. This is an open-access article distributed under the terms of the Creative Commons Attribution License (https://creativecommons.org/licenses/by/4.0/), which permits unrestricted use, distribution, and reproduction in any medium, provided the original work, first published in the 
Journal of Medical Internet Research, is properly cited. The complete bibliographic information, a link to the original publication on https://www.jmir.org/, as well as this copyright and license information must be included. 